\title{
IOWA AT VICKSBURG AND THE VICKSBURG NATIONAL MILITARY PARK.
}

BY COL. J. K. P. THOMPSON.

The National Military Park at Vicksburg, Mississippi, is the outgrowth of "The Vicksburg National Military Park Association," a corporation organized and existing under and by virtue of the laws of Mississippi. It was organized October 23, 1895, and incorporated November 22, 1895. The incorporators included both northern and southern gentlemen, but only those who had served in the Vicksburg campaign.

The officers and directors are as follows:

OFFICERS.

President, Lieutenant-General Stephen D. Lee, Mississippi.

Vice-President, Hon. W. O. Mitchell, Iowa.

Secretary, Captain W. T. Rigby, Iowa.

Treasurer, Colonel C. C. Floweree, Mississippi.

EXEOUTHVE COMMTTTEE.

Colonel J. K. P. Thompson, Iowa; Captain W. W. Stone, Mississippi; Governor W. D. Hoard, Wisconsin; General A. Hickenlooper, Ohio; Captain E. S. Butts, Mississippi.

\section{DIREOTORS.}

Col. J. K. P. Thompson, Iowa. Gen. Geo. F. MeGinnis, Indiana. Col. J. G. Everest, Illinois. Col. Frederick D. Grant, New York. Gen. A. G. Weissert, Wisconsin. Gen. John Sanborn, Minnesota. Gen. Joseph Stockton, Illinois. Col. Lee Rassieur, Missouri. Gen. John S. Kountz, Ohio. Capt. E. S. Butts, Mississippi. Capt. W. W. Stone, Mississippi. Gen. A. Hickenlooper, Ohio.
Col. Harry Weissenger, Kentucky. Capt. J. S. Pilcher, Tennessee. Gen. E. W. Pettus, Alabama. Lieut.-Gen. J. B. Gordon, Georgia. Maj. B. N. Harrod, Louisiana. Gen. J. C. Tappan, Arkansas. Gen. T. N. Waul, Texas. Senator F. M. Cockrell, Missouri. Gen. John P. S. Gobin, Penn. Gen. John M. Wilson, U. S. A. Gov. W. D. Hoard, Wisconsin. Hon. Wm. Olin, Massachusetts. Rear Admiral George Brown, U. S. N., (retired).

When the writer was elected commander of the Department of Iowa, Grand Army of the Republic, in 1895, it was understood that his administration should be signalized by an unyielding and persistent effort to establish a Military 

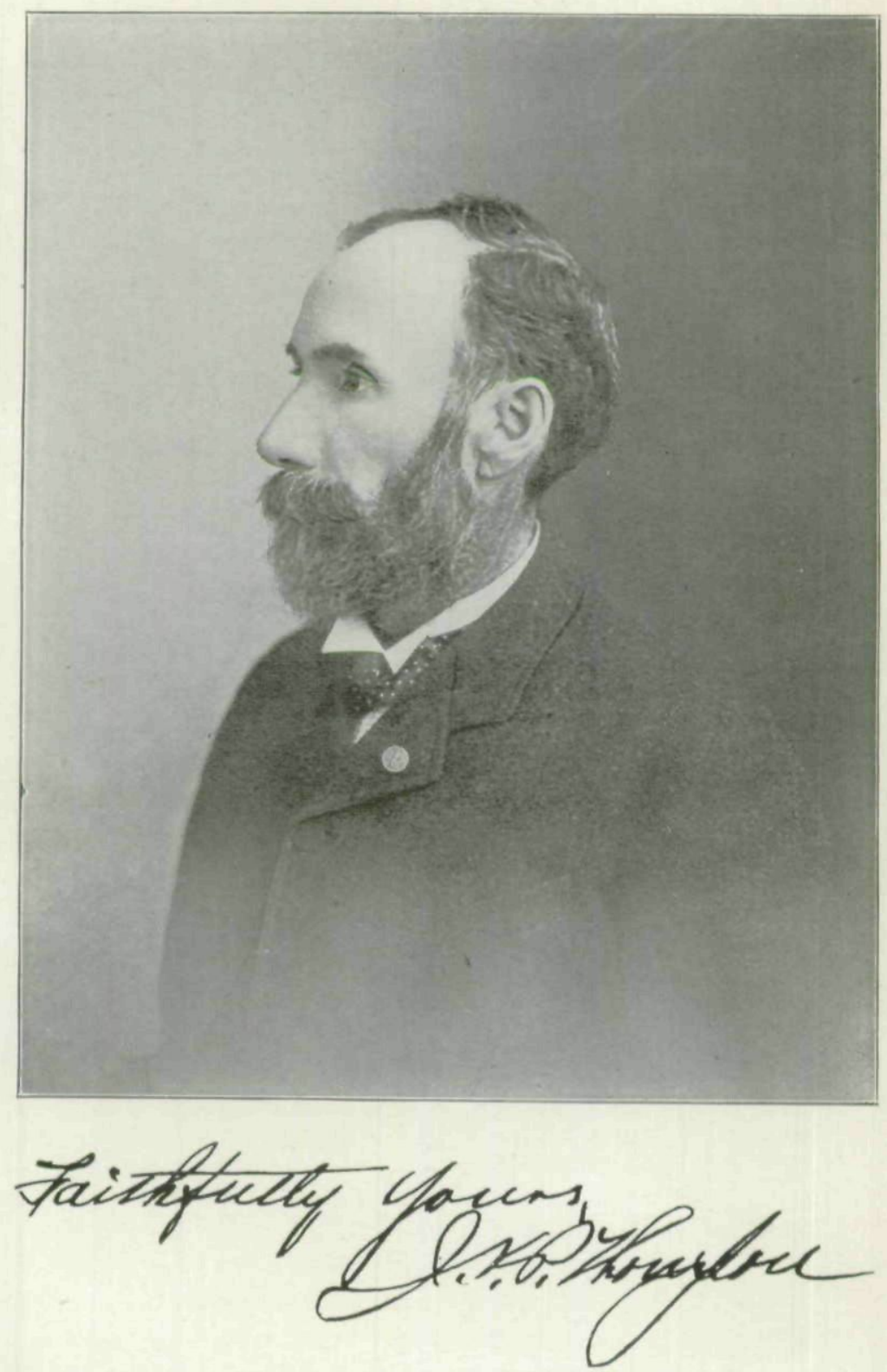

COL. з. К. Р. тномP8ON,

Commander of the Department of Iowa, Grand Army of the Republic, 1895-'96, and a member of the Board of Directors of "The Vicksburg National Military Park Association." 
Park at Vicksburg. His compeers were Capt. J. F. Merry, Capt. W. T. Rigby, Maj. C. L. Davidson, Col. D. J. Palmer, Dr. C, C. Bradley, Hon. W. H. Norris, and many other distinguished Union soldiers of Iowa.

As a result, a resolution favoring the establishment of the park was introduced by the Department of Iowa at the National Encampment, G. A. R., at Louisville, September, 1895, which was unanimously adopted, and the park officially launched, with the endorsement of the National Encampment. At a meeting of the association, November 22, 1895, on motion of Gen. Lucius Fairchild (a member of the first board of directors, but since deceased), it was decided that "The proposed park should include the lines of earthworks of the opposing armies, and the land included within those lines, with such additions as are necessary to include the headquarters of Generals Grant and Pemberton, such of the water batteries as it may be desirable to designate, and other historical spots;" and on motion of Col. Thompson, "The executive committee of the board was instructed to urge upon congress the establishment of a National Military Park on the grounds outlined by the motion of Gen. Fairchild, and where practicable to secure options on the lands included within the lines of the proposed park." Shares of stock were placed at \$5.00, and one hundred shares reported sold and paid for. Gen. Stephen D. Lee, Maj. C. L. Davidson, Col. C. C. Floweree, Capt. E. S. Butts, and Capt. W. T. Rigby, were appointed a committee charged with the duty of preparing a bill for the establishment of the park, of presenting the same to congress, and of obtaining and presenting to congress accurate information as to the cost of the land included in the bill for the proposed park. Pursuant to these instructions, a survey of the premises was made, a map prepared, and options on a large part of the land secured. A bill was prepared and in due time was presented to congress by Gen. Catchings, representing the Vicksburg district. As a result of several weeks of arduous labor, the committee was

Vot. V. -18 . 
enabled to announce a favorable report of the house committee on military affairs, and the bill was placed on the calendar, where it was destined to remain, however, for several years.

During the years of $1895,1896,1897$ and 1898, the friends of the measure were active and unremitting in their efforts to secure the passage of the bill, the secretary, Capt. Rigby, devoting most of his time and energy to its accomplishment. To the indefatigable efforts of Capt. J. F. Merry, formerly of the 21st Iowa, more than to any other person, are we indebted for the establishment of the park. He was untiring and persistent in his efforts, laying railroads, congressmen, legislators, and men of affairs, under constant tribute, till it was truthfully said of him-"What he proposes, that he performs."

In January, 1896, as commander of the Department of Iowa, G. A. R., I issued a circular letterin which attention was called to the measure, and wherein some of the reasons why Iowa should take a leading part in the establishment of the park were set forth. I quote here a portion of the same:

In the reduction of that Gibraltar of the Confederacy, the State of Iowa had so large and distinguished a part-seventy per cent of her total levy being engaged therein*-that it fell with peeuliar fitness to her to take the initiative in this movement. The siege of Vicksburg stands unique and will be memorable in the annals of war. In the science of grand strategy it marked an era. The campaign is without parallel, if we except the picturesque scaling of the Swiss mountains and the descent into Lombardy by the great Napoleon, or his brilliant campaign which terminated at Ulm, and in the opinion of competent military critics, "in boldness of plan, rapidity of execution, and brilliancy of results," eompares most favorably with those of the great Corsican. No field of battle ever witnessed greater deeds of valor than those rugged hills.

The capture of this stronghold was big with results, and was second only in importance to Appomattox itself. It severed the Confederacy in twain, opened the Mississippi to navigation, and in the forcible language

*The following regiments and batteries were engaged in the siege proper: Infantry-The 3d, 4th, 5th, 6th, 8th, 9th, 10th, 11th, 12th, 13th. 15th, 16th, 17th, 19th, 20th, 21st, 22d, 23d, 24th, 25th, 26th, 28th, 30th, 31st, 34th, 35th, 38th, 40th. Cavalry $-3 \mathrm{~d}$ and 4th. Batteries-1st and 2d. The 2d Cavalry was with Hatch in the famous Grierson raid. The 27th Infantry was with Sherman in Gen. Grant's movement to the Tallehatchie, November, 1862, and the 29th, 33d, and 36th were in the famous Yazoo Pass expedition, or 77 per cent of the whole number furnished by the State of Iowa. 
of President Lincoln, "The Father of Waters rolled unvexed to the sea." The loss to the enemy of at least sixty thousand soldiers, one hundred and seventy-two cannon, and sixty thousand stand of arms, was at that time the largest capture of men and material ever made in war.

To quote from an admirable general order, addressed by Gen. Gordon to the United Confederate Camps:

For forty-seven days and nights those blood-stained and storm-crowned heights raged with incessant conflict, and witnessed by turn the assault upon its heroic and stubborn defenders and the repulse of the gallant and obstinate attacking party. By day, sheeted flame issued from every crest of the hills, around this famous citadel of courage, and by night the deadly and destructive boom lighted the heavens with its lurid and baleful light.

Large numbers of the circulars were distributed, and we trust bore good fruit. During the winter of 1895-6 the legislatures of the states of Iowa, Mississippi, New York, Massachusetts, and Rhode Island, each by joint resolution, endorsed the park bill and asked for its passage by congress, as did most of the Department Encampments of the Grand Army of the Republic, and many of the Commanderies of the Loyal Legion, Society of the Tennessee, and the United Confederate Camps. During the winter of 1896-7 the legislatures of the states of Minnesota, Wisconsin, Michigan, Illinois, Indiana, Ohio, and Pennsylvania, each adopted joint resolutions, asking for the establishment of the park, and requesting their delegations in congress to labor to secure the passage of the bill. The Department Encampments of the Grand Army of the Republic and the National Encampment at Buffalo again approved the bill and named committees to promote its passage.

In December, 1897, through the courtesy of Capt. Merry, five members of the House Committee on Military Affairs, Fifty-fifth congress, namely: Hull, Griffith, Belknap, Lentz, and McDonald, visited Vicksburg with a view to ascertaining facts to enable them to judge of the feasibility of establishing and maintaining the park. In January, 1898, Gen. Gobin, Commander-in-Chief, on behalf of the Grand Army of the Republic, Col. Fred. D. Grant, on behalf of the Society of the Army of the Tennessee, and Capt. Rigby, on behalf 
of the Park Association, met in Washington and again urged upon Speaker Reed and the House Committee on Rules the claims of the park bill.

Early in the year 1898 the legislature of the state of Tennessee, by joint resolution, endorsed the bill and asked for its passage by congress. In January, 1899, Capt. Rigby, Hon. W. O. Mitchell, both of Iowa, representing the Park Association, Col. Everest of Illinois, also a member of the association and representing the Society of the Army of the Tennessee, Col. N. M. Hubbard, representing the Department of Iowa, Grand Army of the Republic, again visited Washington in the interest of the park bill, when, being granted an audience with the speaker, Col. Hubbard made one of his characteristic arguments, and a powerful plea for its early consideration. Congressman Henderson (now speaker of the house), Catchings of the Vicksburg district, Griffin, Belknap, Cousins and Hull (both of Iowa), were active and earnest in their support. As a result, Capt. Hull, on February 6, 1899, was recognized by the speaker, the bill called up and promptly and unanimously passed by the house. Four days later it was passed by the senate, and on February 21, 1899, approved by the President.

At the risk of repetition and of being tedious, I have followed the measure, step by step, from its inception, October, 1895 , to the passage of the bill authorizing the establishment of the park, February 21, 1899, for the purpose of showing with what tenacity of purpose its promoters clung to it, and what time and means have been expended in the promotion of this work. The bill, as passed, carried with it an appropriation of $\$ 65,000$ (which has since been increased to $\$ 250$, 000 ) for the purchase of the grounds and improvement of the same. It also provided for the appointment by the Honorable Secretary of War of a commission to consist of three members. The commission, as appointed, consists of Lieut.Gen. Stephen D. Lee of Mississippi, Capt. W. T. Rigby of Iowa, and Col. James G. Everest of Illinois, with Gen. John 


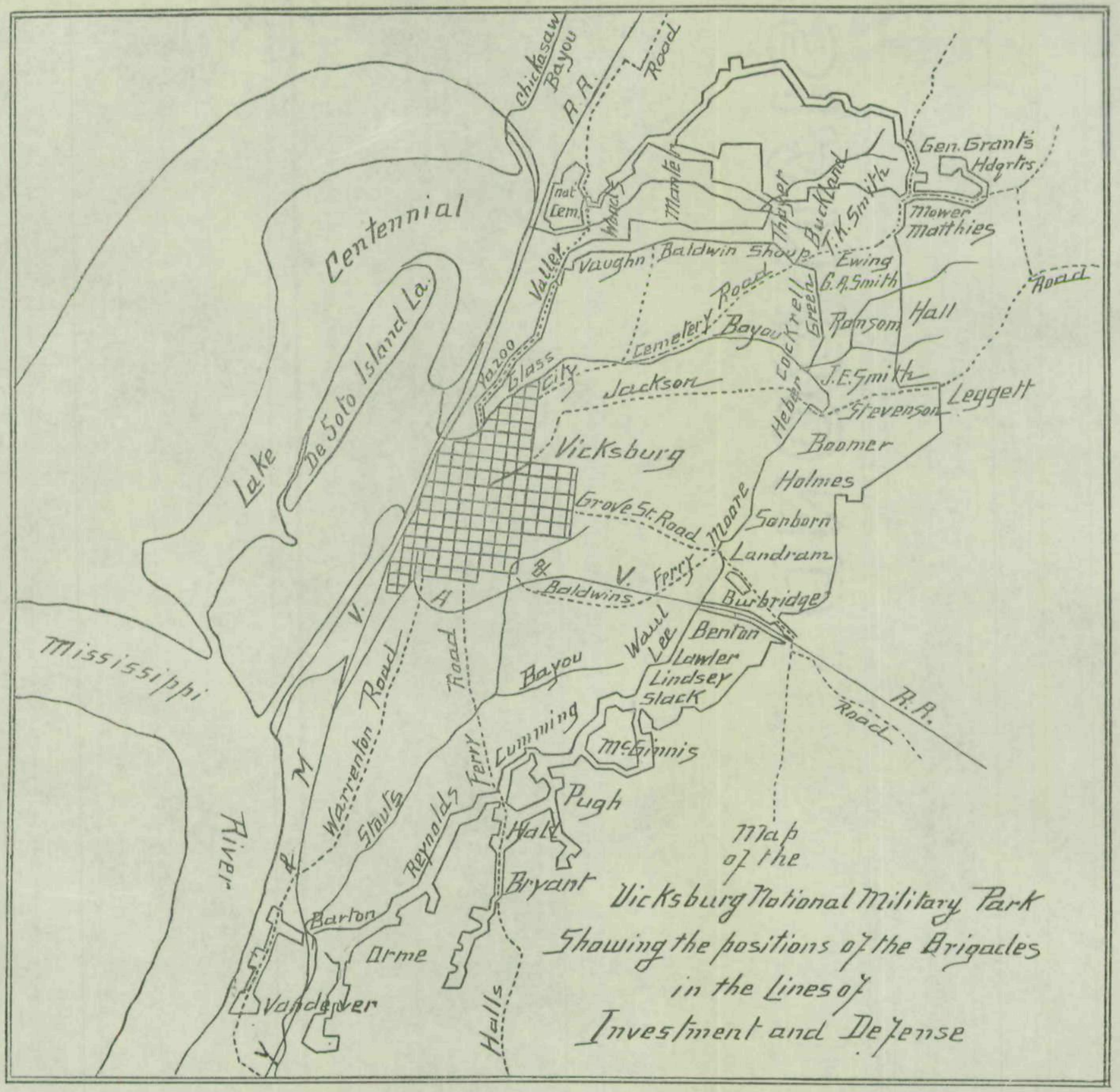


S. Kountz of Ohio as secretary and historian, and Capt. Chas. L. Longley of Iowa assistant secretary.

Section 5 of the act establishing the park reads as follows:

That it shall be the duty of the commissioners named in the preceding section, under the direction of the Secretary of War, to restore the forts and the lines of fortifications, the parallels and the approaches of the two armies, or so much thereof as may be necessary to the purposes of this park; to open and construct and to repair such roads as may be necessary to said purposes, and to ascertain and mark with historical tablets, or otherwise, as the Secretary of War may determine, the lines of battle of the troops engaged in the assaults, and the lines held by the troops during the siege and defense of Vicksburg, the headquarters of Gen. Grant and of Gen. Pemberton, and other historical points of interest pertaining to the siege and defense of Vicksburg within the park or its vicinity.

Authority to mount guns was given by a subsequent act of congress.

It is the purpose of the commission, with the approval of the Secretary of War, to restore substantially the earthworks of the two armies, and to remount all the old guns so far as they can be procured, in their old places. Forts will be restored to their original size and height, ditches opened to their former depth, rifle-pits, parallels, approaches, saps and mines reopened, sap-rollers constructed, placed and maintained in position-in fact, it is the intention to restore the theater of operations as nearly as may be to what it was at the close of the siege July 4, 1863. There are 1232.28 acres within the limits of the park. There will be more than twenty-five miles of costly and artistically built avenues and drives constructed, the precipitous hills graded, the ravines spanned with costly masonry and modern steel bridges, thus affording easy access to and perfect views of what is expected to be the greatest Military Park in the world. There will be an avenue just in the rear of the line of Confederate earthworks eight miles long, one along the main line of the Union earthworks through the main body of the park about five miles in length; one from Union avenue to Gen. Grant's headquarters, and one along the public roads running through the park or along its boundaries. 
Historical tablets, markers and monuments of the Confederate organizations engaged in the defense will be placed on the line of the first named points, and those of the Federals along Union avenue.

The reasons why this famous battlefield should be converted into a great Military Park are various and potent. It was the first really great and determining victory achieved by the Union forces, and was second only in importance to Appomattox itself. It severed the Confederacy in twain, opened up the Mississippi-the great artery of commerce-to navigation, inspired new hope in the north and corresponding gloom in the south, and brought the first great relief to President Lincoln and the loyal millions of the north. The loss to the enemy was at that time unparalleled in the annals of war. Gen. Grant, in his official report, says:

The results of the campaign were: The defeat of the enemy in five battles outside of Vicksburg; the occupation of Jackson, the capital of the state of Mississippi, and the capture of Vicksburg and its garrison and munitions of war; a loss to the enemy of 37,000 prisoners, among whom were fifteen general officers; at least 10,000 killed and wounded, among the killed, Generals Tracy, Tilghman, and Green, and hundreds, and perhaps thousands of stragglers who can never be collected and reorganized. Arms and munitions of war for an army of 60,000 men have fallen into our hands.*

But Gen. Grant was evidently generous to his enemy, for Gen. Badeau, in his "Military History of Gen. Grant," on page 398 , Vol. I, states the total loss to have been $60,000 . \dagger$ When it is remembered that three Confederate divisions did not report, viz.: Baldwin's, Vaughn's, and Dockery's, and that the losses in Loring's division, which was cut off at Cham-

*Official Records, Vol. 24, Part I, page 58.

†The records of the Commissary General of Prisoners show a total of 42,059 prisoners captured during the Vicksburg eampaign after the 1st of May. As Grant lost during that time nearly 9,000 men in killed and wounded, it is fair to suppose that Pemberton and Johnson, so repeatedly and disastrously beaten, lost 12,000. Any one who has seen war is aware how small the estimate, 6,000 , is for stragglers in an unsuccessful campaign. The calculation is simple:

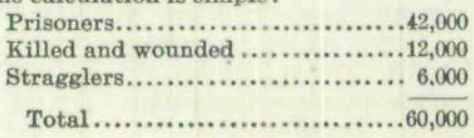


pion's Hill and wandered about for several days and nights before joining Johnson at Jackson, and whose losses were necessarily large, are not given, the discrepancy in the report is easily accounted for.

We doubt if the hardships endured in this campaign, and the exceeding mental and physical strain that was placed upon all, are fully realized by the present generation; drawing two days' rations, which were destined to last many weeks;* marching day and night; bivouacking at night in the rain; water many inches deep; sleeping upon rails, boards, logs, or anything or anywhere that would afford any kind of protection from the drenching rain and water-covered earth. The fatigue and strain upon the troops thus for more than ninety days, was almost unprecedented. Gen. Hovey says: $†$

The strain upon my forces was extreme. For more than forty days they were under constant fire, casualties happening daily in the midst of their camps. Men were killed and wounded in their beds, at the table, and in the rifle-pits.

Col. G. W. Clark, of the 34th Iowa, says:

One-half of my men who were able for duty were on duty all the time. Not unfrequently I was compelled, in order to fill the details, te send men who had just been relieved, thus keeping the same men out in the ditches for forty-eight hours without rest.

\section{D. Ingersoll wrote:}

Out of fifty-six days in those two months the "effective force" of the 4th Cavalry was in the saddle fifty-two.f

Col. Grierson says:

We marched over 600 miles in less than sixteen days (forty miles per day). The last twenty-eight hours we marched seventy-six miles, and had four

*Gen. Grant says in his Memoirs, Vol. I, page 529: "Most of the army had now been for three weeks with only five days' rations issued by the commissary."

Col. Ashbel Smith of the 2d Texas, not always reliable, however, says that his command was "tired, ragged, dirty, barefoot, hungry, covered with vermin, with scanty supply of ammunition; rations reduced to a little more than enough to sustain life, five ounces of musty corn meal and pea flour were nominally issued daily. In point of fact this allowance didn't exceed three ounces."

In an appeal for help addressed to Gen. Pemberton, June 28, 1863, signed "Many Soldiers," it is stated, "Our rations have been cut down to one biscnit and a small bit of bacon per day,-this army is now ripe for mutiny unless it can be fed. Just think of one small biscuit and one or two mouthfuls of bacon per day."

†Page 241, Vol. 24, Part II, Official Records.

‡Ingersoll's "Iowa in the Rebellion," page 422.

||Vol. 24, Part I, page 528, Official Records. 
engagements with the enemy. During this time the men and horses were without food or rest.

\section{Gen. Grant says:*}

Since leaving Milliken's Bend they (the troops) have marched as much by night as by day, through mud and rain, without tents or much other baggage, and on irregular rations.

\section{And on page 35 says-}

Privations have been endured by men and officers as have rarely been paralleled in any campaign.

The strain upon the Confederate forces was even greater than that on the Federal. Gen. Stephen D. Lee says in his report: $\dagger$

The enemy had also from fifteen to thirty pieces of artillery in front of my lines, which kept up a heavy fire during both day and night. There was no relief whatever to our men who were confined for forty-seven days in their narrow trenches without any opportunity of moving about, as there was during the day a perfect rain of minie balls.

There must have been a perfect rain of cannon balls also if we are to believe the report of Gen. John C. Moore, C. S. A.:

Some idea may be formed of the artillery fire to which we were exposed when I state that a small party sent out for that purpose collected some 2,000 shells near and in the rear of the trenches occupied by our brigade. This was soon after the siege began, and it was but a portion of those that failed to explode. Only those who have tried it can tell the effect produced on men by keeping them forty-seven days and nights in narrow ditehes, exposed to the scorching heat during the day, and often the chilly air and dews of night. $\neq$

\section{Gen. Louis Hebert says:}

Forty-eight days and nights spent in trenches, exposed to the burning sun during the day and the chilly air of night, subject to a murderous storm of balls, shells, and war missiles of all kinds, cramped up in pits and holes not large enough to allow them to streteh their limbs; laboring day and night; fed on reduced rations of the poorest kind of food.\|

Sufficient has been said, I think, to establish the fact of the extreme hardships of the campaign and of the privations endured.

*Vol. 24, Part I, page 33, Official Records.

†Vol. 24, Part II, page 351.

$\ddagger$ Ibid, page 382 .

||Vol, 24, Part II, page 377, Official Records. 
Now, let us look for a moment upon the percentage of loss, which in many of the engagements will compare favorably with those of the most sanguinary European battles, either in ancient or modern times.* Gen. Dodge, of the U. S. army, in his "Caesar," $\dagger$ gives a table of casualties in some ancient battles, citing twelve engagements in which there were engaged from 5,000 to 50,000 by the offensive party, in which the average percentage of loss is given at $27+$ per cent. At Waterloo the French lost $21+$ per cent, $\ddagger$ and in the famous charge of the Light Brigade at Balaklava the loss was but $67+$ per cent, and this was but a cavalry dash of a few hundred.\|

The 17th Iowa at Champion's Hill lost in killed and wounded 25 per cent of the number engaged (report of Col. Hillis). Col. Holden Putnam, 93d Illinois, states the strength of his brigade to have been 1,700 men, and his loss at Champion's Hill 510, 30 per cent. Col. E. S. Sampson, 5th Iowa, $\S$ reports his loss to have been 27 per cent. Gen. McGinnis reports his loss at Champion's Hill to have been, in the 11th Indiana 36 per cent, 24th Indiana 40 per cent, and an average per cent of the whole infantry force engaged, 26.20 per cent.

*In Fox's "Regimental Losses," page 46, the percentage of losses in some of the greatest wars and famous battles of the world are given. In the Franco-Prussian war of 1870 the German loss is stated to have been 3.1 per cent. In the Crimean war the allied armies are said to have lost 3.2 per cent-but in the American civil war theloss of the Union forces is given at 4.7 per cent, and the Confederate 9 per cent.

At the battle of Gravelotte, the Germans lost in killed and mortally wounded $14+$ per cent, while Meade's loss at Gettysburg was 25 per cent, and Lee's considerably more. All the historians, we believe, agree that Borodino was the bloodiest battle since the introduction of gunpowder; the most credible statement of the losses sustained places the French loss in killed and wounded at 21 per cent, and the Russian loss at about 22 per cent.

Assuming that Pemberton had but 41,074 men at Vicksburg, his loss being 10,074 would make his percentage of loss (not including those surrendered) at $25+$ per cent. Gen. Stephen D. Lee, in "Publications of the Mississippi Historical Society," says Pemberton's March (1863) returns, show, present for duty, 41,829, which agrees with his total losses and the number surrendered. Grant had 45,000 men when he began the campaign and about 70,000 at the close of the siege; his loss was 10,014 , or $14+$ per cent.

†Dodge's "Caesar," page 781.

$\ddagger$ Bourrienne, Vol. 4, page 180.

||McCarthy's "History of Our Times," Vol. 2, page 576.

§Vol. 24, Part I1, page 316, Official Records. 
The 21st Iowa lost 113 in killed, wounded and missing in the assault on the Confederate works May 22, 1863.* I am unable to determine satisfactorily the number engaged, but assuming it to be the same as the $22 \mathrm{~d}$ Iowa, to-wit: 200 , its loss would be $56+$ per cent. Lieut. Cooley of Company D of the same regiment, in a recent letter states: "When we left for Jackson we had for duty about 160 men. Company D left Vicksburg with 12 men and during the siege of Jackson was reduced to 6 men."

Sergeant E. B. Snedigar, of the same company in a recent letter says: "In the record kept by Capt. Boardman I find 'our regiment lost fully one-half in killed and wounded on the $22 \mathrm{~d}$ of May.'"

Geo. Crooke, adjutant of the regiment, says in his "History of the Twenty-first Iowa," on page 112, "The regiment numbered for effective service less than 200 men and officers, and arrived at Jackson mustering only 158 men for duty."

In a letter received recently from Wm. Fobes, a private in Company $\mathrm{D}$, he states that he was the only private soldier in the company reporting for duty at that time.

Lieut.-Col. Harvey Graham, of the 22d Iowa, says in a communication addressed to Maj. Gen. McClernand, Sept. 1, $1863,+$ that the strength of his regiment in the assault upon the Confederate works May 22, 1863, was 200. The loss of the regiment; was 164 or 82 per cent, far exceeding the loss of the Light Brigade made famous by Lord Tennyson.

A useless and criminal loss occurred at Jackson, Miss., July 12, 1863, in the brigade commanded by Col. I. C. Pugh, of the 41st Illinois, through the incompetency and criminal negligence of Gen. Lauman. The brigade went into action with 880 officers and men and lost 465 or 53 per cent. Thus the estimate placed upon his ability by C. A. Dana was verified.

*Vol, 24, Part II, page 161, Official Records.

† Vol. 24, Part I, page 178.

$\ddagger$ Vol. 24, Part II, page 161 .

"lLauman is a brave man, but an ox is just as flt to command." Official Records, Vol. 24, Part I, page 108. 
The 3 d Iowa lost on that day 47 per cent of those engaged.

Col. Waul, of the Texas Legion, reports a loss of more than one-third of his command.* Maj. Gen. John H. Forney a loss in his division of 24 per cent. Gen. S. M. Barton† says the loss in his brigade at Champion's Hill was over 42 per cent.

The troops marched from 12 to 28 miles per day; the 5th Iowa, 16 miles for six consecutive days; Gen. Ewing's brigade, 85 miles in three days - 28 miles per day. Gen. Bowen says that "Gen. Tracy's brigade marched 100 miles, fought for twelve hours an army of five times their number, and all in the space of five days."

When it is remembered that these men carried not only their weapons and probably an average of forty rounds of cartridges, their rations, such as they had, knapsacks, and in fact furnished the transportation as well as the fighting machines for the army, it will readily be seen to what extreme fatigue they were exposed, and to what a trial their endurance was subjected.

By an act of the General Assembly of the State of Iowa, approved March 29, 1900, the governor was authorized to appoint a commission "To ascertain and exactly determine the positions of the Iowa troops in the campaign and siege of Vicksburg." Under the provisions of this act the governor appointed a commission, of which the writer was elected chairman. The commission visited Vicksburg in November, 1900 , and duly located the several positions of the Iowa troops. Commissioners from the states of Massachusetts, Rhode Island, Ohio, Minnesota, Missouri and Mississippi, have also visited the park and located the positions of their troops. Commissioners from the states of Texas, Tennessee and Illinois will perform their work at an early date. It is

\footnotetext{
*Vol, 24, Part II, page 358, Official Records. $\dagger$ †bid, page 100.
} 
expected that commissions will be authorized and appointed from every state which had troops in Grant's, Pemberton's and Johnston's armies. The State of Iowa was the second state to locate positions, having been preceded a few days by Massachusetts.

The following statement shows the Union military organizations in the Vicksburg campaign:

Illinois-Infantry, 52; Cavalry, 10; Artillery, 15; total .. 77

Indiana-Infantry, 24; Cavalry, 2; Artillery, 2; total... . 28

Iowa-Infantry, 28; Cavalry, 2; Artillery, 2; total ..... 32

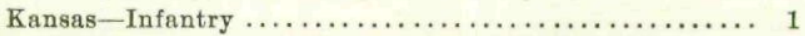

Kentucky-Infantry, 3 ; Pioneers, 1 ; total........... 4

Massachusetts-Infantry .................. 3

Michigan-Infantry, 7 ; Artillery, 2 ; total.......... 9

Minnesota-Infantry, 3; Artillery, 1; total .......... 4

Missouri-Infantry, 17; Cavalry, 3; Artillery, 7; total... 27

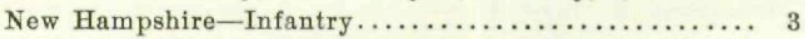

New York-Infantry, 3; Artillery, 1 ; total .......... 4

Ohio-Infantry, 26; Cavalry, 1; Artillery, 11; total ..... 38

Pennsylvania-Infantry, 4; Artillery, 1 ; total ........ 5

Rhode Island-Infantry $\ldots \ldots \ldots \ldots \ldots \ldots \ldots \ldots \ldots \ldots \ldots$

Regulars-Infantry, 2; Artillery, 1; total........... 3

West Virginia-Infantry ................. 1

Wisconsin-Infantry, 13; Cavalry, 1; Artillery, 3; total . . 17

This makes an aggregate of 192 regiments or parts of regiments of infantry, 19 regiments of cavalry, and 46 batteries of artillery -257 organizations, not including eight regiments of negroes in process of enlistment.

The Confederate strength under Gen. Pemberton at Vicksburg was as follows:

Alabama-Infantry, 9; Artillery, 3; total............ 12

Arkansas-Infantry, 5; Cavalry, 1; Artillery, 2; total.... 8

Georgia-Infantry, 10; Artillery, 1 ; total............. 11

Louisiana-Infantry, 7 ; Artillery, 18; total.......... 25

Missouri-Infantry, 5; Cavalry, 2; Artillery, 5; total.... 12

Mississippi-Infantry, 13; Artillery, 9; total.......... 22

Maryland-Artillery ........................... 1

Tennessee-Infantry, 7; Cavalry, 1; Artillery, 8; total... 16

Texas-Infantry, 3 ; Cavalry, 1 ; Artillery, 1 ; total ...... 5

Virginia-Artillery $\ldots \ldots \ldots \ldots \ldots \ldots \ldots \ldots \ldots \ldots \ldots \ldots \ldots \ldots$ 
This including "City Guards," and "Partisan Rangers," credited to Mississippi, and, in the total, three companies "paroled" as "Signal Corps," with no state named, makes an aggregate of 62 regiments or parts of regiments of infantry, 5 of cavalry, and 49 batteries of artillery-116 organizations. At the same time Gen. Johnston appears to have had with him 85 regiments or parts of regiments of infantry, 3 of cavalry, and 14 batteries of artillery-102 organizations.

The following compilation of "Classified Casualties" in Iowa troops during the siege of Vicksburg and connected with the campaign from November, 1862, to the beginning of the siege proper, and after the close of the same, July 4, 1863 , to the evacuation of Jackson, Miss., July 18, 1863, was furnished me by Adj. Gen. Melvin H. Byers, and is the work of Major T. F. Stephens, that most efficient, painstaking and obliging record clerk of the Iowa adjutant general's office. It is made from the written record of each regiment participating and will be found, I think, substantially correct. It differs, however, in several particulars from the table furnished by the United States Park Commission. This is notably true in the 21 st, $23 \mathrm{~d}$, and 24 th Infantry. It will thus be seen that Iowa lost 422 killed and 44 missing (who were doubtless among the killed), 151 captured, and 1,816 wounded, a total of 2,433 . 


\section{IOWA AT VICKSBURG.}

Casualties classified in Iowa organizations during the siege of Vicksburg, Miss., from May 19 to July 4, 1863, and in battles, raids, scouts, and skirmishes prior to the siege and closely connected therewith, from November, 1862, and in the operations against Jackson, Miss., and its siege and evacuation, July 17, 1863, as taken from the records and Adjutant General's Reports of 1867 .

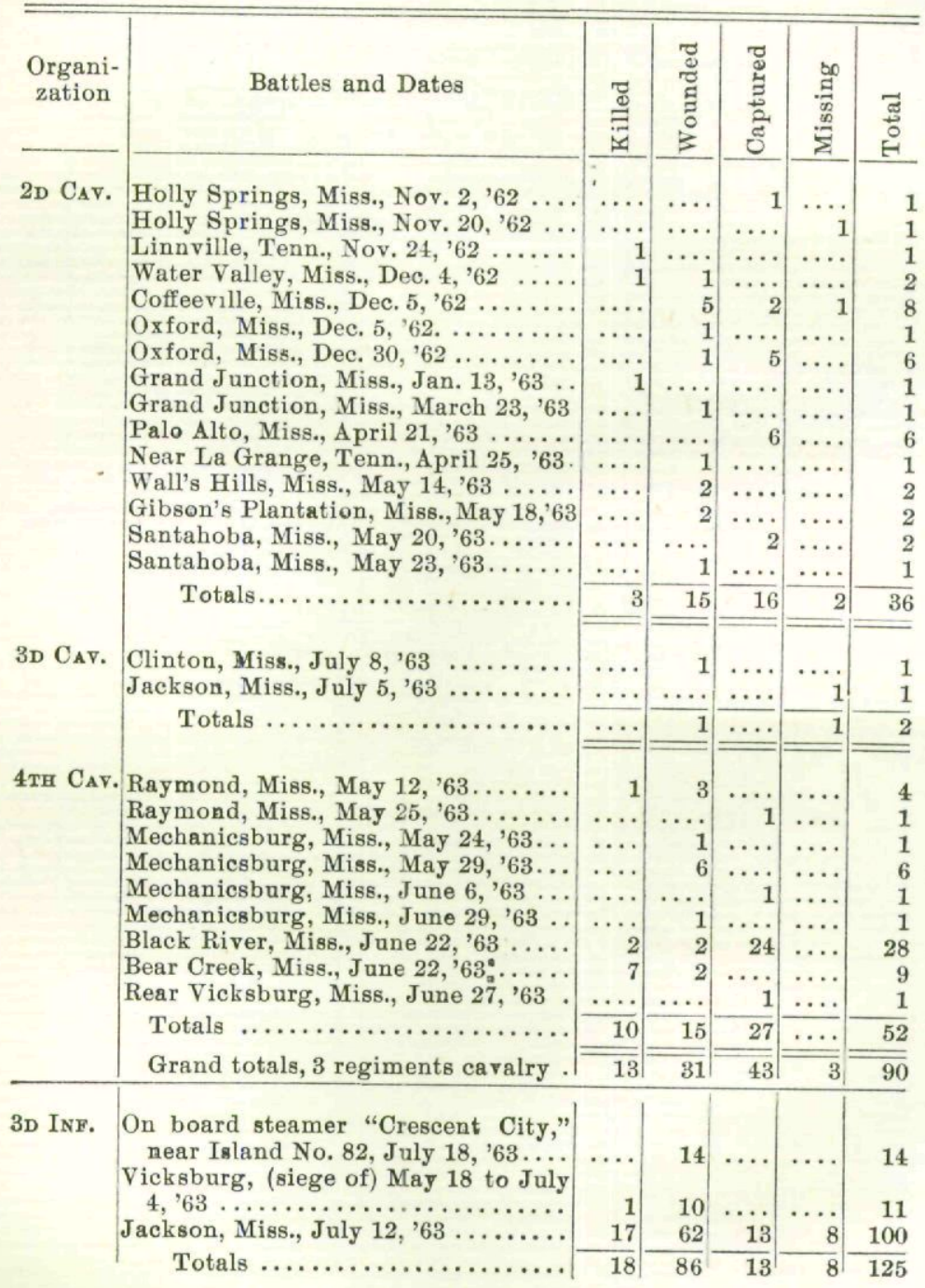




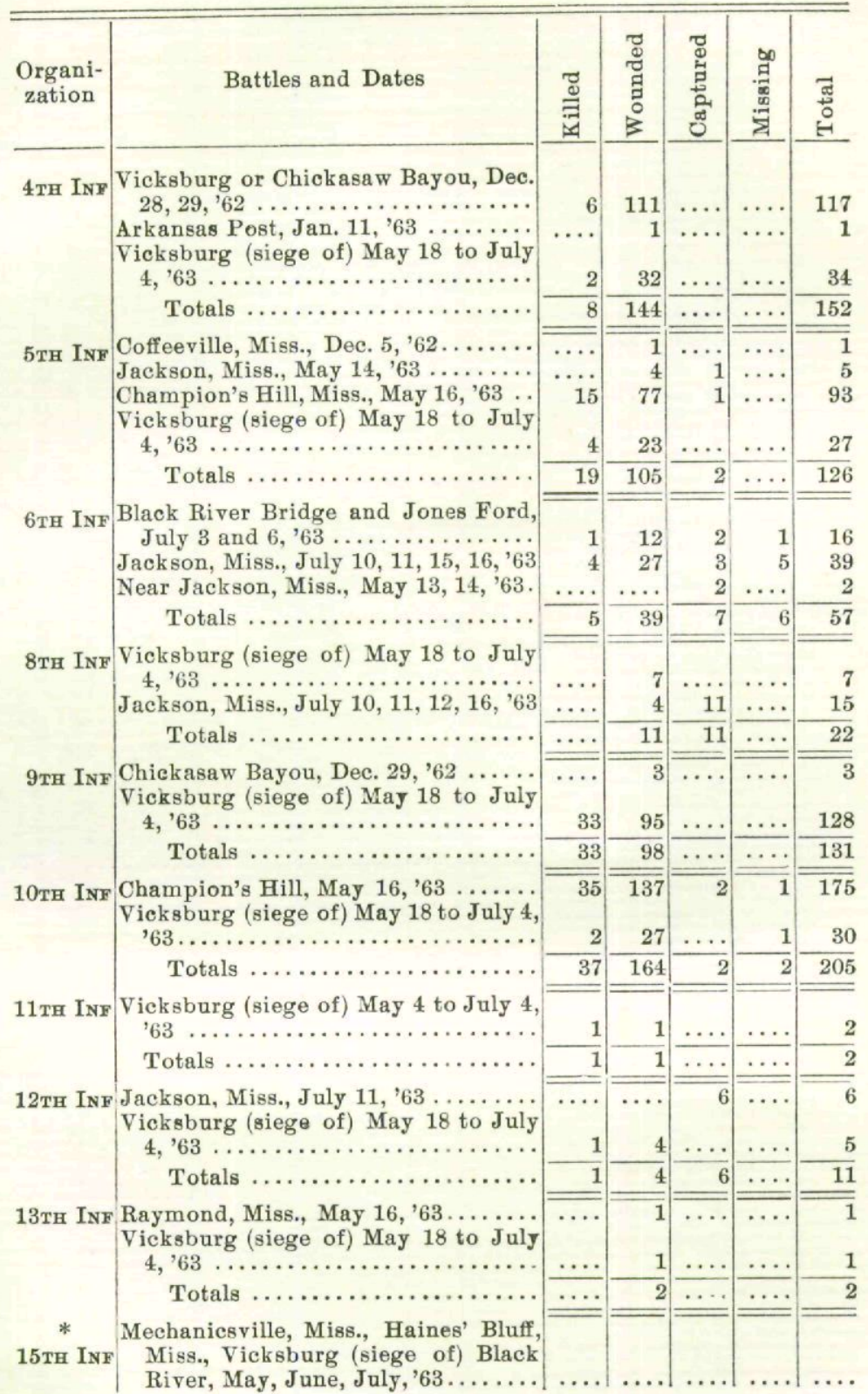

*Record does not show any casualties in this regiment in the Vicksburg campaign. 


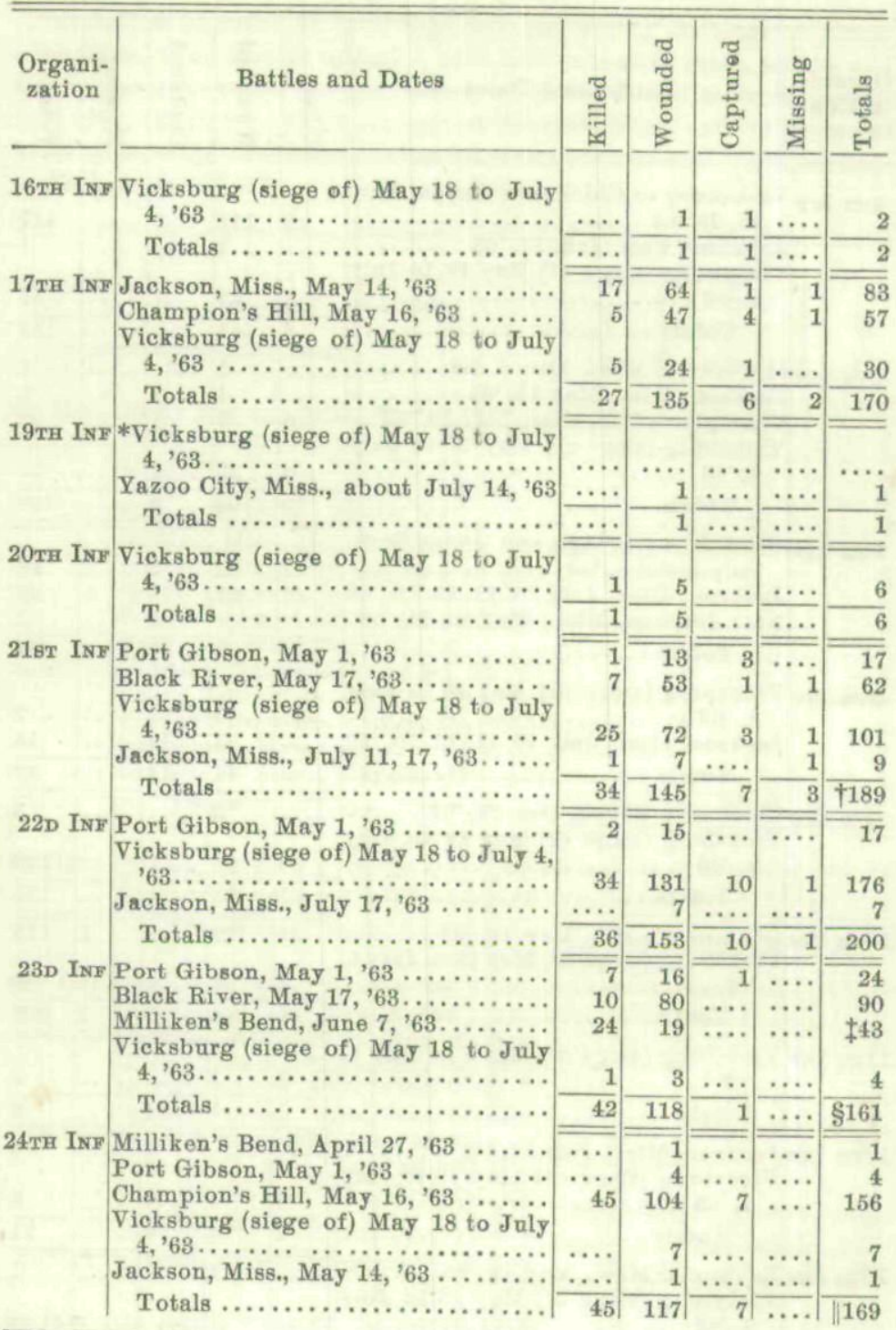

*Record shows no casualties.

†The U. S. Commissioner's figures, Art. 217.

†See Official Records, Part I, vol. 24, page 96. Loss 86.

gThe U. S. Commissioners' figures, Art. 229.

॥The U. S. Commissioners' figures, Art. 200. 


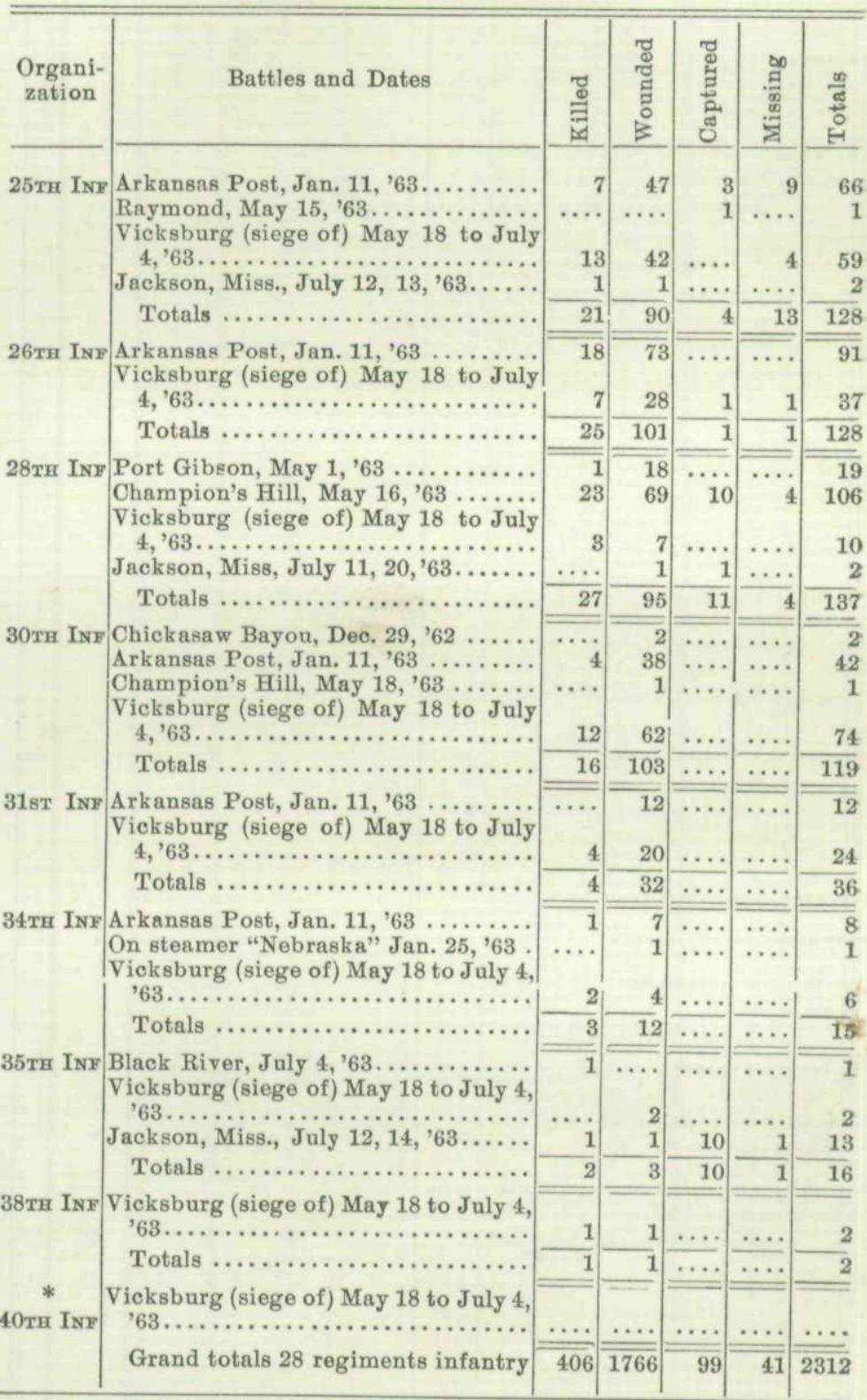

*Ordered to Haines' Bluffs May 31, '63, to take part in Vicksburg campaign, but had no casualties. In "Army of Observation"-so called.

VoL, V.-19. 


\begin{tabular}{|c|c|c|c|c|c|c|}
\hline $\begin{array}{c}\text { Organi- } \\
\text { zation }\end{array}$ & Battles and Dates & 泀 & 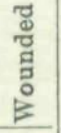 & 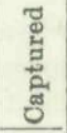 & 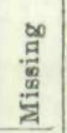 & ङึ \\
\hline \multirow{3}{*}{$\begin{array}{r}\text { Lt. Artil } \\
\text { 1st BAT }\end{array}$} & Port & & 3 & & & 3 \\
\hline & 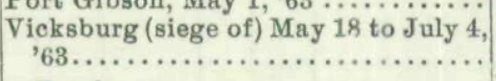 & 1 & 5 & … & & 6 \\
\hline & Totals $\ldots \ldots \ldots \ldots \ldots \ldots \ldots \ldots \ldots$ & 1 & 8 & $\ldots$ & $\cdots$ & 9 \\
\hline \multirow[t]{3}{*}{ 2D BAT } & 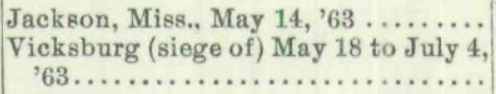 & $\cdots \cdot$ & 1 & $\bar{\cdots}$ & $\cdots$ & 1 \\
\hline & Totals $\ldots \ldots \ldots \ldots \ldots \ldots \ldots \ldots \ldots$ & 1 & 5 & $\ldots$ & $\cdots$ & 6 \\
\hline & Grand totals, 2 batteries artillery.. & 2 & 13 & $\bar{\cdots}$ & $\bar{\cdots}$ & 15 \\
\hline
\end{tabular}

SUPPLEMENTARY TABLE.

\begin{tabular}{|c|c|c|c|c|c|c|}
\hline 27 TH INF & Near Waterford, Miss., Nov., Dec., '62 & .... & 2 & 2 & $\ldots$ & 4 \\
\hline $29 \mathrm{TH}$ INF & Yazoo Pass, April, ' $63 . . . \ldots \ldots \ldots \ldots$ & $*_{1}$ & $\cdots$ & $\ldots$ & $\ldots \ldots$ & 1 \\
\hline $33 \mathrm{D}$ INF & Yazoo Pass, Feb., '63 .............. & .... & $\ldots$. & 7 & $\ldots$. & 7 \\
\hline $36 \mathrm{TH}$ INF & Yazoo Expedition, Feb., '63 ......... & $\ldots$. & 4 & $\ldots \ldots$ & $\ldots$ & 4 \\
\hline & Grand totals, 4 regiments infantry & 1 & 6 & 9 & $\ldots$ & 16 \\
\hline
\end{tabular}

SUMMARY.

\begin{tabular}{|c|c|c|c|c|c|}
\hline avalry, 3 regiments $. . . \ldots \ldots \ldots . .$. & 13 & 31 & 43 & 3 & 90 \\
\hline Infantry, 28 regiments $\ldots \ldots \ldots \ldots \ldots \ldots \ldots \ldots$ & 406 & 1766 & 99 & 41 & 2312 \\
\hline 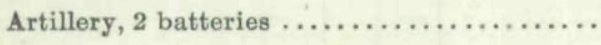 & 2 & 13 & $\cdots \cdots$ & $\cdots$ & 15 \\
\hline Infantry, 4 regiments (supplementary table). & 1 & 6 & 9 & $\ldots$ & 16 \\
\hline 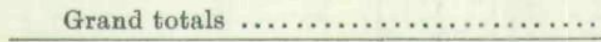 & 422 & 1816 & 151 & 44 & 2433 \\
\hline $\begin{array}{c}\text { Casualties at siege of Vieksburg (proper), } \\
\text { May } 18 \text { to July } 4,1863 \ldots \ldots \ldots \ldots \ldots \ldots \ldots \ldots\end{array}$ & 154 & 619 & 16 & 8 & 797 \\
\hline $\begin{array}{l}\text { Casualties all other engagements in the Vicks- } \\
\text { burg oampaign from Nov. } 1862 \text {, to July 18, } \\
1863 \text {, aside from siege proper } \ldots \ldots \ldots \ldots \ldots \ldots\end{array}$ & 268 & 1197 & 135 & 36 & 1636 \\
\hline Grand totals.......... & 422 & 1816 & 151 & 44 & 2433 \\
\hline
\end{tabular}

*Drowned in Tallehatchie river. 
Adjutant Generax's Offioe,

Des Mornes, Iowa, Oetober 16, 1901.

Col. J. K. P. Thompson, Rock Rapids, Iowa:

Deas Colones: Replying to your inquiry of October 15, I beg to submit the following list of organizations and troops furnished by the State of Iowa during the War of the Rebellion, as taken from Adjutant General N. B. Baker's Report for 1865 .

M. H. BYers,

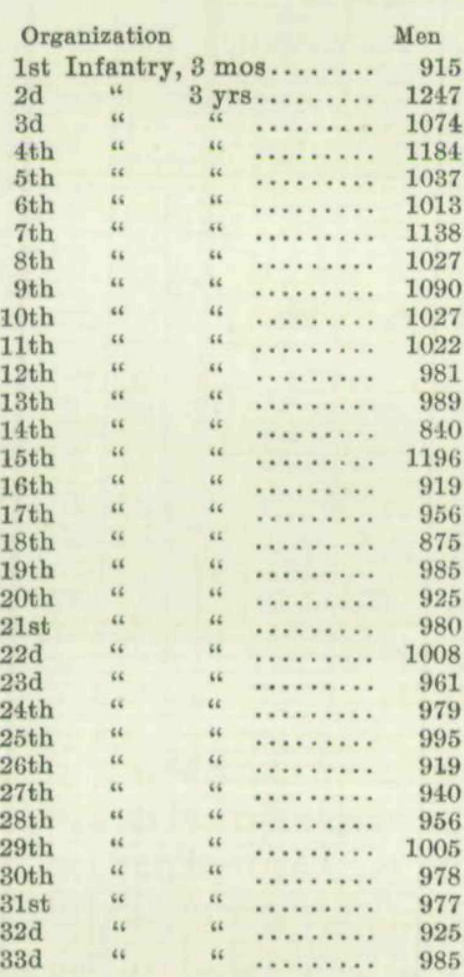

Adjutant General.

\begin{tabular}{|c|c|c|c|}
\hline \multicolumn{3}{|c|}{ Organization } & Men \\
\hline \multicolumn{3}{|c|}{ 34th Infantry, 3 yrs......... } & 953 \\
\hline 35 th & " & $\ldots \ldots \ldots$ & 984 \\
\hline 36 th & $"$ & $\ldots \ldots \ldots$ & 986 \\
\hline 7 th & “ & $\ldots \ldots \ldots$ & 914 \\
\hline 8th & $"$ & $\ldots \ldots \ldots$ & 910 \\
\hline 99 th & " & $\ldots \ldots \ldots$ & 933 \\
\hline 40th & " & $\ldots \ldots \ldots$ & 900 \\
\hline 41st & 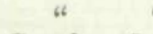 & *battalion & 294 \\
\hline 1st & Cavalry, 3 & rs........ & 1478 \\
\hline $2 d$ & " & $\ldots \ldots \ldots$ & 1394 \\
\hline $3 d$ & " & $\ldots \ldots \ldots$ & 1360 \\
\hline 4 th & $"$ & $\ldots \ldots \ldots$ & 1227 \\
\hline 5 th & “ & $\ldots \ldots \ldots$ & 1245 \\
\hline 6 th & " & $\ldots \ldots \ldots$ & 1125 \\
\hline 7 th & " & $\ldots \ldots \ldots$ & 562 \\
\hline 8 th & $"$ & $\ldots \ldots \ldots$ & 1234 \\
\hline 9 th & " & $\ldots \ldots \ldots$ & 1178 \\
\hline *Sior & ux City Cav: & $\operatorname{lry}, 3$ yrs... & 93 \\
\hline Co. A & 11th Penn. & avalry 3 yrs & 87 \\
\hline 1st & Battery, 3 y & $3 \ldots \ldots \ldots$ & 149 \\
\hline $2 \mathrm{~d}$ & 4 4 & $\ldots \ldots \ldots \ldots$ & 123 \\
\hline $3 \mathrm{~d}$ & $" 6$ & $\ldots \ldots \ldots$ & 142 \\
\hline 4th & " 6 & $\ldots \ldots \ldots$ & 152 \\
\hline $\begin{array}{c}\text { 1st I. } \\
\text { U. }\end{array}$ & $\begin{array}{l}\text { owa African } \\
\text { S......... }\end{array}$ & $\begin{array}{l}\text { Inf. or } 60 \text { th } \\
\ldots \ldots \ldots \ldots\end{array}$ & 903 \\
\hline Dods & ge's Brigade & Band ...... & 14 \\
\hline Ban & of $2 \mathrm{~d}$ Iowa & Infantry... & 10 \\
\hline $44 \mathrm{tl}$ & Infantry, 1 & 0 days.... & 867 \\
\hline $45 \mathrm{tl}$ & $" 6$ & $" \quad \ldots \ldots$ & 912 \\
\hline 46th & " & $\ldots \ldots$ & 892 \\
\hline 47 th & 4 & $\ldots \ldots$ & 884 \\
\hline 48th & (battalion) & $\ldots \ldots$ & 346 \\
\hline
\end{tabular}

Total. ............ 56,344

Enlistments as far as reported to January 1, 1864, for the older Iowa

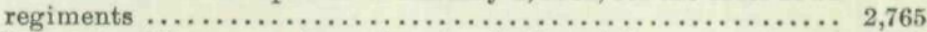

Enlistments of Iowa men in regiments of other states......... 2,500

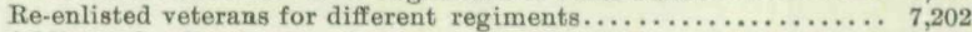
Additional enlistments $\ldots \ldots \ldots \ldots \ldots \ldots \ldots \ldots \ldots \ldots \ldots \ldots \ldots \ldots \ldots, 6,664$

Brought forward $\ldots \ldots \ldots \ldots \ldots \ldots \ldots \ldots \ldots \ldots \ldots \ldots \ldots \ldots \ldots \ldots \ldots \ldots \ldots, 344$

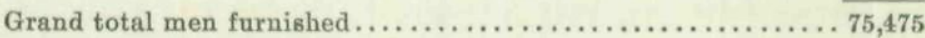

NotE-The $42 \mathrm{~d}$ and $43 \mathrm{~d}$ regiments of Infantry were ordered raised and numbers assigned (42 and 43 ) but they were never flled. Those (few) enrolled for these numbers were distributed as recruits among old regiments.

*Afterwards consolidated with 7th Cavalry. 
General summary of casualties in the Union forces during the operation against Vicksburg, May 1 to July 4, 1863, as shown by the Official Records:

The aggregate loss, including the battles of Port Gibson, Raymond, Jackson, Champion's Hill, Black River, Milliken's Bend, and Vicksburg, and numerous skirmishes in the meantime, was 10,014 .

Summary of the casualties of Confederate forces in the Vicksburg campaign, as shown by the Official Records:

Port Gibson, Smith's and Stevenson's divisions .............. 832

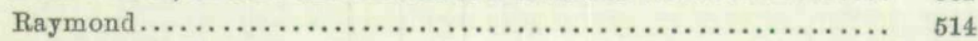

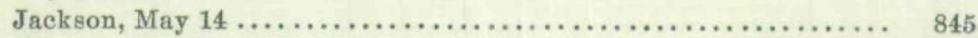

Champion's Hill $\ldots \ldots \ldots \ldots \ldots \ldots \ldots \ldots \ldots \ldots \ldots \ldots \ldots \ldots \ldots \ldots \ldots, 3,624$

Black River Bridge $\ldots \ldots \ldots \ldots \ldots \ldots \ldots \ldots \ldots \ldots \ldots \ldots \ldots \ldots, 1,024$

Vieksburg (Baldwin, Vaughn and Dockery not reporting) ....... 2,872

Milliken's Bend ..................................... 725

Partial report of Baldwin and Vaughn $\ldots \ldots \ldots \ldots \ldots \ldots \ldots \ldots \ldots, \quad 40$

Total......................................

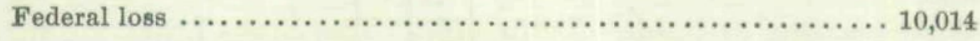

Excess of Confederate loss ....................... ${ }_{462}$

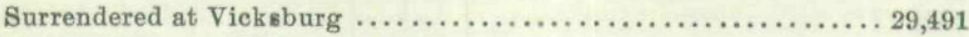

Captured by expeditionary armies $\ldots \ldots \ldots \ldots \ldots \ldots \ldots \ldots \ldots \ldots, 1,147$

Killed, wounded and missing (as above) $\ldots \ldots \ldots \ldots \ldots \ldots \ldots \ldots \ldots \ldots \ldots \ldots \ldots \ldots, 476$

Total Confederate loss ....................... $\overline{41,114}$

Add to this those not reported and those who died in hospitals before paroling could be completed, and those who escaped or concealed themselves, together with the stragglers, and one can readily reconcile the numbers with those given by Gen. Badeau.*

*Official Records, Vol, 24, Part I, page 58.

IN A word, we may gather out of history a policy no less wise than eternal, by the comparison and application of other men's forepassed miseries with our own like errors and ill-deservings.-Sir Walter Raleigh. 
Copyright of Annals of Iowa is the property of State of Iowa, by \& through the State Historical Society of Iowa and its content may not be copied or emailed to multiple sites or posted to a listserv without the copyright holder's express written permission. However, users may print, download, or email articles for individual use. 